\title{
Lidia Mikołajuk
}

Biblioteka Uniwersytetu Łódzkiego

e-mail: lidia.mikolajuk@lib.uni.lodz.pl

\section{Zjazd Koalicji Otwartej Edukacji (Jabłonna, 8-9 sierpnia 2017 r.)}

DOI: http://dx.doi.org/10.18778/0860-7435.25.15

Koalicję Otwartej Edukacji (dalej: KOED) tworza polskie organizacje pozarządowe oraz instytucje działające w obszarze edukacji, nauki i kultury. Koalicja ta została założona 27 listopada 2008 r. przez cztery organizacje reprezentujące naukę i edukację: Stowarzyszenie Bibliotekarzy Polskich, Interdyscyplinarne Centrum Modelowania Matematycznego i Komputerowego Uniwersytetu Warszawskiego, Fundację Nowoczesna Polska oraz Stowarzyszenie Wikimedia Polska. Uniwersytet Lódzki przystapił do KOED w 2015 roku. Z każdym rokiem powiększa się liczba koalicjantów; obecnie jest to blisko 40 instytucji i organizacji. Misją Koalicji Otwartej Edukacji jest wspieranie tworzenia otwartych zasobów edukacyjnych i promowanie związanych z nimi dobrych praktyk i narzędzi (Nasza misja, 2017). Idea, która przyświeca Koalicji, jest przekonanie, że wiedza to dobro publiczne i wszyscy powinni móc swobodnie $z$ niej korzystać. KOED promuje otwarte zasoby edukacyjne rozumiane jako treści z szeroko pojętego obszaru edukacji, nauki i kultury, udostępniane w sposób gwarantujący wszystkim swobodny i bezpłatny dostęp oraz prawo kopiowania, ponownego wykorzystania: przetwarzania, modyfikowania i remiksowania w dowolnym celu.

Koalicja jest koordynatorem obchodów Tygodnia Otwartego Dostępu, Tygodnia Otwartej Edukacji oraz Dnia Domeny Publicznej. Istotnym elementem działań stowarzyszenia jest praca nad przygotowaniem opinii i rekomendacji w kluczowych zagadnieniach związanych z prawem autorskim, na- 


\section{Lidia Mikołajuk}

uką i edukacją. Prawnicy współpracujący z KOED przygotowuja analizy prawne, mające forsować korzyści otwartych rozwiązań w tych obszarach.

Raz w roku przedstawiciele organizacji koalicyjnych spotykają się na zjeździe federacji, będącym okazją do podsumowania zrealizowanych przedsięwzięć, wymiany doświadczeń oraz przygotowania planu działania na następny okres. Tegoroczne spotkanie zorganizowano w dniach 8-9 sierpnia w pięknych wnętrzach pałacu w Jabłonnie pod Warszawa. Zjazd rozpoczął przewodniczący KOED, Kamil Śliwowski, który przedstawił sprawozdanie z działań zrealizowanych przez Koalicję w minionym roku (rys. 1). Wymienił Festiwal Aplikacji i Gier Mobilnych, który KOED objął swoim patronatem. Wiele miejsca poświęcił obchodom Dnia Domeny Publicznej, zorganizowanych w Krakowie i Warszawie oraz Tygodniowi Otwartej Edukacji, w ramach którego przeprowadzono cykl spotkań w 12 miastach oraz szkolenie w formie webinarium. Omówił przygotowana petycje Reforma Prawa Autorskiego dla Edukacji, której celem jest powiększanie domeny publicznej, rozszerzanie dostępu do nauki i sztuki oraz swobodnego korzystania z nich. Wymienił zorganizowane przez KOED webinaria: Domena Publiczna w kulturze, Wieczorne rozmowy o Otwartej Edukacji oraz Re-use w muzeach, bibliotekach i archiwach.

Rys. 1. Wystapienie Kamila Śliwowskiego

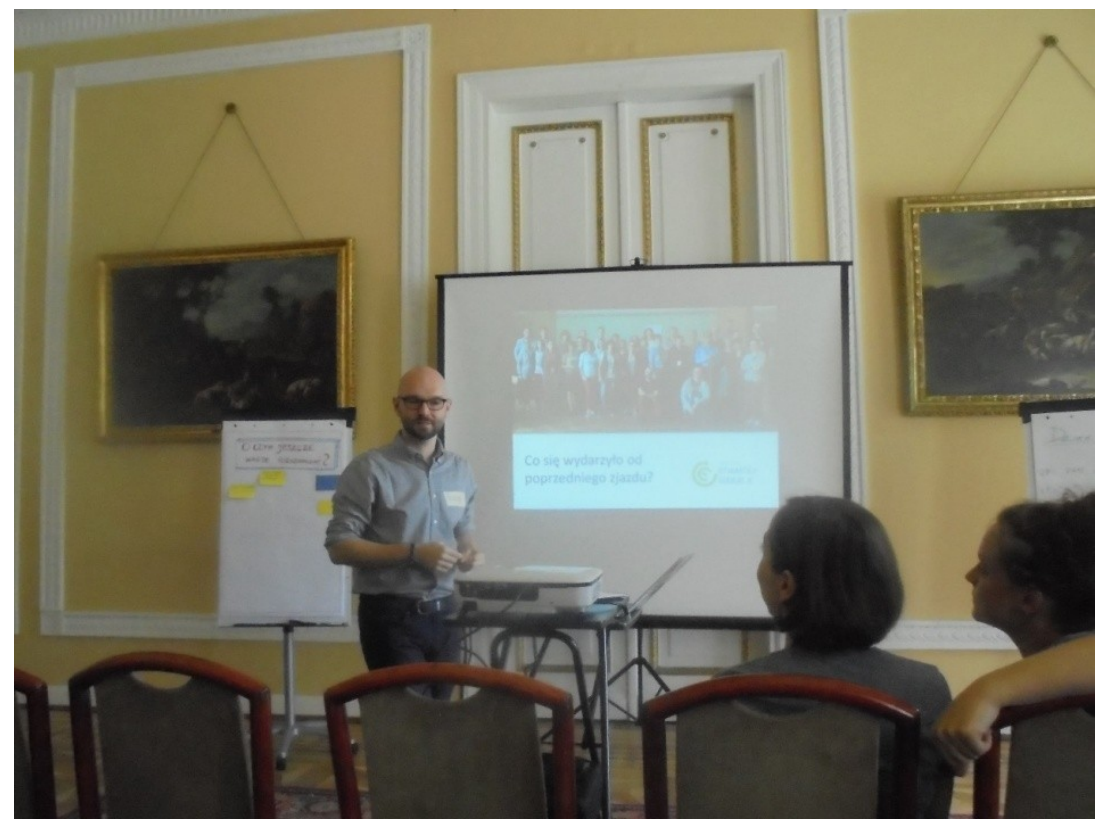

Źródło: Fot. L. Mikołajuk 


\section{Zjazd Koalicji Otwartej Edukacji...}

Kolejnym punktem programu były warsztaty prawne, prowadzone przez Alka Tarkowskiego i Natalię Mileszyk, którzy przedstawili projekt dyrektywy Unii Europejskiej w sprawie praw autorskich na jednolitym rynku cyfrowym. Jest to istotny dokument dla wszystkich zaangażowanych w debatę nad reforma prawa autorskiego, z uwagi na nowe wyzwania, które stoja przed regulacjami prawnymi w czasach Internetu. Prelegenci omówili dozwolony użytek gwarantujący podmiotom badawczym, edukacyjnym i instytucjom kultury możliwość korzystania z utworów przy pomocy narzędzi nowych technologii. Skomentowali również propozycję nowych praw wydawców, które mogłyby stać się zagrożeniem dla domeny publicznej. Zwrócili uwagę na niektóre sposoby korzystania przez serwisy internetowe $z$ treści chronionych. Budzą one wiele wątpliwości ze względu na brak precyzyjnego określenia relacji pomiędzy nowymi przepisami a dotychczasowymi zasadami odpowiedzialności pośredników internetowych. Obowiązujące reguły ułatwiaja prywatną cenzurę i nie daja użytkownikom praktycznych narzędzi do obrony.

Karolina Grodecka przygotowała dla uczestników zjazdu warsztaty Podstawy prowadzenia webinarów (rys. 2). Podczas zajęć położyła nacisk na kwestie praktyczne. Punktem wyjścia było określenie adresata konkretnego webinarium. Bardzo istotnym elementem działań wstępnych jest planowanie otoczenia dla osoby prowadzącej webinar, zadbanie o właściwy kadr, oświetlenie i dźwięk. Kolejnym etapem jest opracowanie scenariusza, zdefiniowanie celu, przygotowanie treści zajęć i zarezerwowanie czasu na pytania i działania uczestników. W planie webinarium należy uwzględnić takie elementy, jak zapoznanie się ze słuchaczami, eksploracja stanu ich wiedzy na temat przedmiotu szkolenia, zawartość merytoryczna oraz wdrożenie - wciagnięcie uczestników w dialog i aktywizowanie ich. K. Grodecka zalecała również podział wystapienia na 10-minutowe moduły oraz zastosowanie dużej liczby slajdów w prezentacji, co ułatwi właściwy odbiór wykładu.

Warsztaty prowadzone przez Monikę Koblak poświęcone były nauce obywatelskiej. Zagadnienie to definiowała ona jako aktywne i dobrowolne działania wolontariuszy, zaangażowanych w projekty badawcze. Jest to pojęcie wielofunkcyjne, które można adaptować i stosować w rozmaitych sytuacjach i dziedzinach. Nauka obywatelska uznawana jest za podejście badawcze, daje też szansę szerszego zaangażowania społecznego i demokratyzacji nauki. W trakcie warsztatów podawano wiele przykładów takich praktyk, jak np. Projekt Galaxy Zoo, BioWeatherMap. Uczestnicy warsztatów zastanawiali się, czy możliwe jest zastosowanie takiej formy działalności w ich jednostkach macierzystych. 


\section{Lidia Mikołajuk}

\section{Rys. 2. Warsztaty Podstawy prowadzenia webinarów}

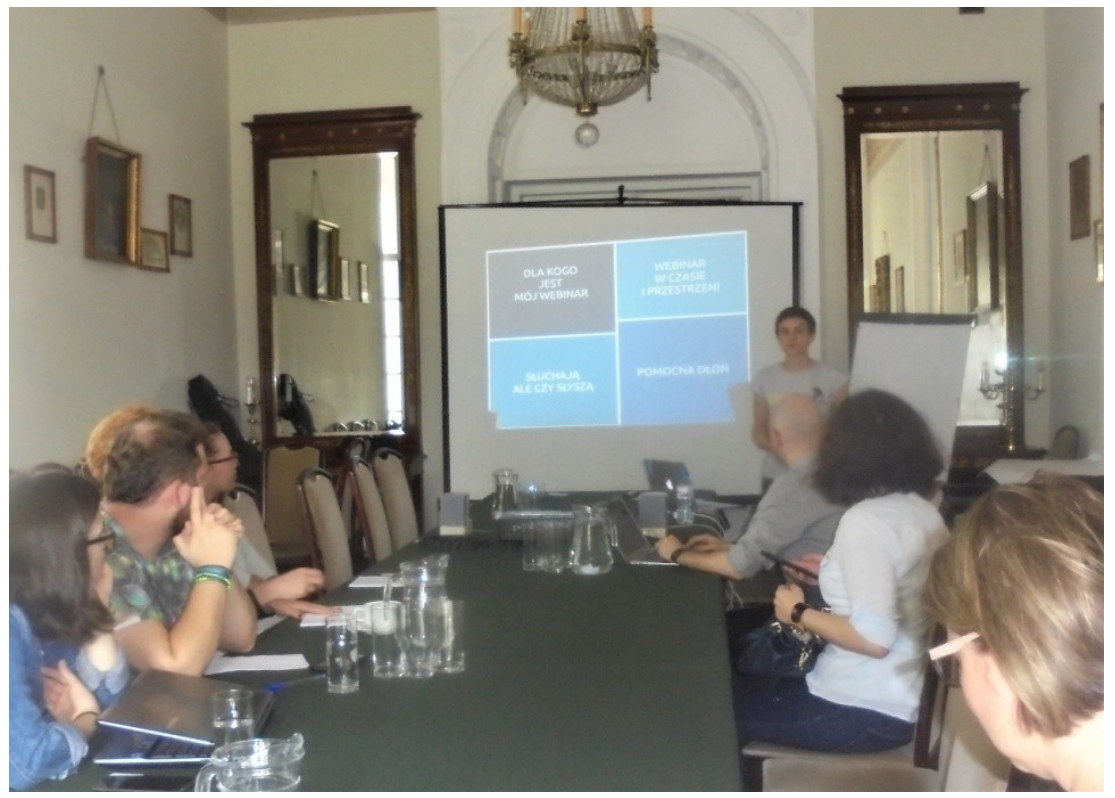

Źródło: Fot. L. Mikołajuk

Tomasz Ganicz przedstawił projekty Wiki GLAM. Stowarzyszenie WikiMedia Polska współpracuje z polskimi muzeami, archiwami, bibliotekami, galeriami oraz innymi instytucjami kultury i dziedzictwa i działa na rzecz wzbogacenia biblioteki mediów o reprodukcje dzieł sztuki, materiały archiwalne, fotografie, filmy czy nagrania oraz ich ponowne wykorzystanie w artykułach Wikipedii. Instytucje kultury udostępniaja swoje zbiory znajdujące się w domenie publicznej lub przekazuja do Wikimedia Commons wybrane materiały na wolnych licencjach (GLAM-WIKI, 2017). W swojej prezentacji T. Ganicz przybliżył projekty Etno-Karpaty, Ślady ognia, Faras oraz Nowoczesne archiwa społeczne.

Alicja Pacewicz (Centrum Edukacji Obywatelskiej) mówiła na temat otwartości społecznej w edukacji. W swoim wystapieniu przedstawiła szkołę, rozumiana jako społeczność uczniów, nauczycieli i rodziców. Zachęcała do poprawienia wzajemnej komunikacji i relacji między tymi grupami oraz wprowadzania zmian w duchu wspólpracy i otwarcia się na potrzeby całego środowiska szkolnego. Duży nacisk położyła na planowanie zespołowe, badanie potrzeb i oczekiwań społeczności szkolnej oraz działania praktyczne. Podawała wiele przykładów szkół, które wprowadziły nowe formy pracy z uczniami i uzyskały wymierne korzyści edukacyjne. 


\section{Zjazd Koalicji Otwartej Edukacji...}

Ważną część programu zjazdu KOED stanowiły warsztaty nad zaplanowanymi wspólnymi działaniami w roku akademickim 2017/2018. Wymieniono wśród nich szkolenie dla prawników z instytucji i organizacji, instruktaż wypełniania obowiązków ustawowych w zakresie otwartości dla instytucji publicznych, organizację cyklu webinariów, publikację nowych i zaktualizowanych materiałów na temat otwartości w edukacji i kulturze. Drugi moduł warsztatów stanowiła praca w trzech grupach, które przygotowały szczegółowy plan organizacji Tygodnia Otwartej Nauki, Dnia Domeny Publicznej oraz Tygodnia Otwartej Edukacji.

Ostatnim punktem był wykład Karola Piekarskiego (Medialab Katowice) na temat projektu badania kultury poprzez dane, zrealizowanego w ramach platformy „Shared Cities”. Badano w nim wpływ wydarzeń kulturalnych na przestrzeń miejską Katowic. Jego celem jest skupienie osób i społeczności zaangażowanych w projekty kulturalne, społeczne i architektoniczne.

Uczestnicy zjazdu KOED z uwagą wysłuchali wszystkich wystąpień, zyskując inspirację do nowych działań. Był to także czas na dyskusję, wymianę poglądów i dotychczasowych doświadczeń.

\section{Bibliografia}

Nasza misja (2017). Koalicja Otwartej Nauki. Pobrane 10 sierpnia 2017, z: http://koed.org.pl/ $\mathrm{pl} /$ nasza-misja/

GLAM-WIKI (2017). Stowarzyszenie Wikimedia Polska. Pobrane 10 sierpnia 2017, z: https://pl.wikimedia.org/wiki/GLAM/ 